\title{
Issues for School Libraries in the Pacific: A Case Study - Western Samoa
}

\author{
Dr. Janet Murray, \\ Director, Murray Consulting \& Training, \\ PO Box 329, Ocean Grove, Victoria 3226, \\ Australia \\ murray@gsat.edu.au \\ Jacinta Godinet, \\ Chief Librarian, Department of Education, Western Samoa \\ PO Box 598, Nelson Memorial Public Library, \\ Apia, \\ Samoa \\ jpgodinet@lesamoa.net
}

\begin{abstract}
This paper reviews the literature and previous research about the development of school libraries in South Pacific countries. Then the practical issues currently facing school libraries in the South Pacific are considered, drawing on recent experiences in Samoa, where the authors have worked together on the upgrading of libraries in government schools. Some of the issues arising from this work, and possible solutions, are discussed.
\end{abstract}

\section{Introduction}

Since March 2001, the authors have worked together on the upgrading of libraries in government schools in Western Samoa. Some of the issues to be addressed in school library provision in Samoa, in all school sectors, are similar to those experienced in many other developing countries. In commencing this project, the authors looked at previous research reported about the development of school libraries in both the South Pacific countries and other developing countries, in order to learn from previous experiences. This literature is reviewed, and then some background information about Samoa and its education system is provided. The issues that emerged in the Samoan project and some possible solutions are then discussed.

\section{Literature Review}

This review considers research previously conducted in South Pacific countries and also reports on some work done in other developing countries that was relevant to the Samoan experience. To attempt to review all literature on school libraries in developing countries is beyond the parameters of this paper.

The main thrust of previous work in the South Pacific centred on the UNESCO South Pacific School Libraries Project, which ran from 1978 until 1991. It aimed to improve school libraries in the eleven independent states: Cook Islands, Fiji, Kiribati, Nauru, Niue, Papua New Guinea, Solomon Islands, Tonga, Turaw, Vanuatu, and Western Samoa. Some training programs for teachers and school library staff were designed and strategies developed to 
deliver library services to isolated rural populations (Hallein 1992, 1993). This project was also discussed in a paper presented in Australia (Hallein \& Poston-Anderson 1992). A workshop held under the auspices of the project, in Suva in 1981, recommended the development of some short courses for training school librarians and to educate teachers about the use of school libraries. These courses were subsequently written by a team of Australian library educators and were published by UNESCO in 1979. Some training was delivered in Sydney, Australia in 1985 and in Western Samoa in 1986 and in Vanuatu in 1987, 1990, and 1991. The Vanuatu workshops initially concentrated on storytelling and drama as a means of encouraging literacy. Later workshops focussed on providing specific library skills to those teachers who held responsibility for school libraries.

Woolls (1992) has suggested ways of addressing the problems faced by developing countries in school library provision. She suggests that schools should use desktop publishing to create materials for school libraries. These include materials such as biographies of students' friends and families, and documenting local culture and folklore. She also recommends the audio recording of oral traditions and storytelling. This approach addresses to some extent the lack of materials in general, and especially those in indigenous languages. But to do this schools need a computer, desktop publishing software and supporting CDROMs, a binding machine, tape recorders and possibly digital cameras.

Many of the issues about the provision of school libraries in developing countries have been comprehensively addressed by Dilke (1994). Firstly the challenge of introducing libraries where there has been no culture or tradition of library provision and use is highlighted, and this involves using new and different approaches. She suggests that one of the most significant issues is the differing levels of provision ranging from none at all in some small rural schools through to relatively sophisticated provision including access to electronic information available in some urban secondary schools and independent schools. She reports that very few purpose built libraries exist in developing countries, and often there are only nominal library collections administered by the principal or by school students under the supervision of a teacher. A lack of infrastructure to support regular electrical power and telephone services represents a particular barrier to establishing libraries that can provide access to electronic information in a range of formats and through the Internet. Dilke also draws attention to the environmental conditions in some countries where the use of fans and air-conditioners affects the maintenance of library collections.

Sothik (1999) describes the problems addressed in establishing school libraries in Cambodia where war has resulted in a critical lack of books and any library infrastructure. These problems are also faced by some small Pacific countries, although for different reasons; problems such as few trained librarians, few outlets for purchasing books, few libraries, school libraries which are a collection of old outdated books, or where the few decent books are locked away in a cupboard for fear they might be damaged if used.

The lack of professional expertise in developing countries is addressed by Knuth (1999). The small number of trained school librarians leads to a lack of networking and professional support, and a lack of professional literature with a local focus. Knuth also discusses the possibilities of school library development in developing countries being supported by public libraries, but finds that often public library infrastructure and support offered by government is too weak for this to be viable. Some countries have used a model of joint-use school/public libraries, especially in rural areas. Also in countries where the 
education system is strongly oriented to textbook based learning, the role of school libraries may not be understood or seen to be irrelevant.

The review of the literature alerted the authors to many problems that were present in Samoa, but also reminded us that there would be problems that are common to school libraries all over the world. These include a lack of understanding of the role of the library in the school, and a lack of trained staff, particularly in primary schools. Often teachers themselves do not have well-developed skills in locating and accessing information. The school library can be a focus for improved information literacy skills for students, teachers and the wider school community.

\section{Samoa-Background}

Samoa consists of nine islands located in the Pacific Ocean. The estimated population (projected from the 1991 census) live on the two main islands of Upolu and Savai'i. These two islands are connected by a vehicular ferry and air transport services, and roads are good on both islands. Thus Samoa does not face the problems experienced by several other Pacific countries, of vast distances and small isolated population centres. Over twenty percent of the population live in the main town of Apia with most of the remaining population being in small rural villages on the two main islands. Population growth has been low, due to external emigration patterns.

Samoa has a small open economy, largely dependent on agriculture and agroprocessing industries, and heavy reliance on development assistance. Severe economic setbacks have been experienced as a result of two major cyclones in 1990 and 1991.

\section{Schools in Samoa}

Education has been prioritised in the Government of Samoa's economic strategy (2000) with the chief focus being the equitable access to quality education for all children in the Samoan education system. There are nine key areas for development during the final five years of the Education Department's strategic plan covering 1995-2005:

- Encourage the development of early childhood education;

- Improve the overall quality of primary education;

- Increase access to secondary education;

- Meet the educational requirements of children with special needs;

- Strengthen teacher education;

- Improve the responsiveness of post secondary education by facilitating stronger linkages with secondary schools;

- Increase support for non-formal education;

- Improve policy formulation, planning and management within the Education Department;

- Improve primary and secondary school management.

(Government of Samoa, Education Department 1999)

There are just over two hundred government, independent and church schools in Samoa, catering for approximately 54,000 primary and secondary students ${ }^{\mathrm{i}}$. School attendance is compulsory from the ages of 5 to 14 . Four government secondary colleges are directly managed by the Department of Education. The remaining government schools are built and maintained by village communities, with staffing and educational provision 
provided by the Department of Education. Classes are conducted both in English and Samoan. There are three independent schools in Samoa and thirty five church schools administered by a range of religious denominations.

\section{Libraries in Samoa}

There is limited library infrastructure in Samoa. There is a public library, the Nelson Memorial Public Library (NMPL) in Apia, which also acts by default as the National library. The NMPL also has a library in Salelologa on the island of Savai'i. This public library service is administratively part of the Education Department. The NMPL has been funded by the National Library of Australia through its Regional Cooperation Program, for the last three years. This funding has provided computers and also training in computerised cataloguing and the use of DB/Textworks. The NMPL previously administered a mobile library service for schools on both islands, operating two vehicles to visit schools and exchange deposit collections. This service ceased operation some years ago due to vehicle breakdown, but currently the Education Department is taking steps to reinstate it.

There are three academic libraries in Samoa - at the National University of Samoa, the Samoa Polytechnic and at the Alafua Campus of the University of the South Pacific. There are several small special libraries in government departments, donor agencies and nongovernment organisations.

Although there is a very small number of professionally qualified librarians in the country, there is an active Library Society that has membership from both the librarians and library staff and interested members of the general community. There are two small bookshops in Samoa.

\section{The Development of School Libraries in Samoa}

Most of the problems identified in the literature review exist in Samoa. The level of school library provision varies enormously from none at all, to comparatively sophisticated libraries in some of the privately funded schools or government colleges. Very few government schools have a school library. Those that exist are in converted classrooms, usually equipped with home made shelving and stocked with materials discarded from libraries in developed countries. Often these materials are not appropriate either from a subject or reading level context. Some secondary schools have teachers who hold responsibility for the administration of the library. Two of the four government senior colleges do have reasonably equipped libraries. One of these (Avele College) was redeveloped and moved to a larger building, with the aid of the authors and the staff of the NMPL, during 2001. The other, at Samoa College, is longer established and provides electronic information resources as well as books.

Because there are few school libraries the two branches of the NMPL are used intensively by school students outside of school hours. But for students who live in isolated rural communities the use of a public library is not an option.

There are several issues to be addressed in developing school library provision in Samoa. These include the lack of qualified library staff, the paucity of materials in indigenous languages and collection maintenance in tropical climates. Donations of largely irrelevant and outdated library materials from libraries and service organisations in more developed 
countries are not necessarily a benefit. As well as the lack of qualified library staff, many teachers also need staff development programs to help them understand how the school library can be used to support the curriculum. In the past various strategies have been used in Western Samoa to overcome these problems, such as the mobile library service to rural communities, intensive staff development programs run by school library educators from overseas countries, and the use of inexpensive and easily accessible resources, such as puppets and drama to encourage the development of literacy programs.

\section{Current Approaches}

The Education Department has recognised that school libraries have an important role in the achievement of its current strategic plan. The standard of existing school libraries needs to be raised, and school libraries established in schools that currently do not have a library. The Department also needs a library to support its own staff, such as administrative staff, curriculum support specialists and school review officers. The Department also hopes to develop a resource centre for teachers on the island of Savai'i, which will be situated adjacent to the public library. It is hoped that a teacher reference collection will be included in this centre.

The placement of the public library service within the Education Department is a positive factor in the provision of school libraries. Firstly, although the public library has only one fully trained librarian on its staff, the staff nevertheless have a range of valuable experiences in libraries and education. Several of the staff are currently pursuing library education programs through distance education from the University of the South Pacific (USP). The NMPL also has the benefits of links with other libraries in the region, such as the National Library of Australia, as mentioned above, as well as links with the USP Library, which strives to offer support to other libraries in the Pacific (Mills 1992). There are examples of successful models in countries such as the UK where school libraries are staffed, maintained and supported through a public library service that is aligned to an Education department within government, and there is no reason why this cannot be a successful approach for Samoa. However, as Knuth (1999) has pointed out, this approach requires sufficient funding and infrastructure support from the government for the public library.

The Education Department is currently working, with the assistance of the Asian Development Bank (ADB), on a project that will significantly improve the quality of education offered in several government primary and secondary schools on Upolu and Savai'i. Each redeveloped school in the project will have a new school library. Our challenge is to plan and equip these libraries in a way that is sustainable. These libraries will then become models for other schools to follow in providing libraries. The ADB has recently completed a similar project in the Cook Islands, so we have been able to learn from experiences there. The library buildings will not have fans or air conditioners, so building design has emphasised air circulation as a primary feature. Selecting library resources has presented particular challenges in finding material that is at high interest level and culturally appropriate, whilst being at an appropriate reading level in English. Finding resources published in Samoan has also been difficult, but we are working cooperatively with the National Library of New Zealand on this.

Internet access for government schools in Samoa is not currently viable, due to the high cost of telecommunications. The village communities are responsible for the maintenance of schools and the cost of a telephone is too high for most. There are also 
problems related to the inconsistent quality of telephone lines across rural Samoa and some parts of Apia, the main town. However in order to provide Samoan students with the opportunity to learn to use electronic information, computers and CDROM resources will be provided in school libraries in the project schools.

Perhaps our greatest challenge is the provision of appropriate training. There are a few teachers in government schools who have some library training. In the project schools teachers will be given responsibility for libraries and they will need some basic library survival skills, to be followed by professional training for some, who can then mentor and support others. As each new school library is set up, we hope to find volunteer school librarians from other countries who will came to Samoa to work alongside teachers in charge of libraries for several weeks, teaching them library skills in a one on one situation. We hope that we may gain some support for this from the recently established IASL International Volunteer Assistance Program (IVAP). Aside from the training of teachers who are managing libraries, teachers in general need to be educated about the role of school libraries in supporting the curriculum, as well as in encouraging literacy and recreational reading. Many still see the library as a part of the English curriculum, which is an idea not that long gone from many schools in developed countries.

An important outcome of our work has been the production of Standards for School Libraries in Samoa (Murray \& Godinet 2001) that will become part of the Education Department's general standards for schools.

\section{Conclusion}

The provision of a school library service may often be the only means available to students to access both printed and electronic information, in countries such as Samoa, where public libraries, bookshops and other outlets for published information are scarce. In Samoa, there are opportunities for school libraries in rural areas to be developed as a resource for the community as well as the school.

Currently the availability of electronic information resources and use of the Internet have opened up new exciting possibilities for the delivery of school library services in South Pacific countries. In Samoa for example, there are several Internet Service Providers who are well aware of the possibilities for school libraries in delivering information electronically, and are keen to be involved in the development of these services. Thus as telecommunication standards improve, students in Samoan schools will eventually have the opportunity to access electronic resources using communications technology equivalent to that used by their counterparts in other countries, and develop the necessary information skills to locate, handle and use information from a range of sources effectively. However, in Samoa as in other Pacific countries, future planning must incorporate the provision of school libraries managed to a professional standard whilst considering what is culturally appropriate. This requires a range of approaches to facets of the service such as staff development and training, acquisition and collection maintenance, and design of library buildings, to ensure sustainable development. 


\section{References}

Dilke, V.W. (1994). Issues in school librarianship in developing countries. Access 8 (2) May, 24-32.

Government of Samoa (2000). Partnership for a Prosperous Society. Apia: Treasury Department.

Government of Samoa, Education Department (1999). Education Mini-Summit "Taking Strategic Control" Final Report. Samoa: National University of Samoa.

Hallein, J. (1993). Australia's contribution to international school librarianship. in Dreams and dynamics: Selected papers from the Annual Conference of the International Association of School Librarianship, Adelaide, South Australia, September 27-30.

Hallein, J. (1992). UNESCO School Libraries in Oceania project. in Annual Conference of the International Association of School Librarianship, Belfast, Northern Ireland, July 20-24, 1992.

Hallein, J. \& Poston-Anderson, B. (1992). Australia's role in school library development in the South-west Pacific. in Libraries: The heart of the matter. Proceedings of the Australian Library and Information Association $2^{\text {nd }}$ Biennial Conference. Canberra: Australian Library and information Association. pp. 131-132.

Knuth, R. (1999) On a spectrum: International models of school librarianship. Library Quarterly 69 (1) January, 33-56.

Mills, Carol (1992). The University of the South Pacific in its region; professional support and small Pacific libraries. in Libraries: The heart of the matter. Proceedings of the Australian Library and Information Association $2^{\text {nd }}$ Biennial Conference. Canberra: Australian Library and Information Association. pp. 241-244.

Murray, J.R. \& Godinet, J.P. (2001) Standards for School Libraries in Samoa. (Unpublished).

Sothik, H. (1999). Setting up children's libraries in Cambodian primary schools. School Libraries in View 12, Autumn, 15-17.

UNESCO (1979). South Pacific Region Pilot Project on School Library development: Training programs for teachers PG1-84/WS/13. Cited in Hallein, J. \& PostonAnderson, B. (1992) Australia's role in school library development in the South-west Pacific. in Libraries: The heart of the matter. Proceedings of the Australian Library and Information Association $2^{\text {nd }}$ Biennial Conference. Canberra: Australian Library and information Association. pp. 131.

Woolls, B. (1992). Creating elementary and secondary school libraries: A basic approach in Annual Conference of the International Association of School Librarianship, Belfast, Northern Ireland, July 20-24, 1992.

\footnotetext{
'Government of Samoa Education Department, Planning and Research Un it, 2000.
} 